\title{
Community-scale Flood Risk Management: Effects of a Voluntary National Program on Migration and Development
}

\author{
Douglas S. Noonan, Abdul-Akeem Sadiq
}

\section{Introduction}

Floods remain the most destructive natural hazard worldwide in terms of lives lost, property damage, and economic impact (Jonkman, 2005; Sadiq \& Noonan, 2015a). For example, in 2012, flood victims ${ }^{1}$ accounted for $53 \%$ of all victims of natural disasters worldwide (GuhaSapir, Hoyois, \& Below, 2013). Moreover, the Intergovernmental Panel on Climate Change (IPCC) has predicted increases in the frequency and intensity of heavy precipitation events and melting of glacier ice (IPCC, 2013). Against the backdrop of future increase in climate changeinduced flood risks, flooding is likely to continue to wreak havoc on ecological and human systems (Botzen et al., 2009; IPCC, 2013). How we collectively address these challenges to community resilience is becoming increasingly important in the face of changing risks and urbanization.

Understanding and improving flood management at the community scale (i.e., levels larger than the individual or household, but smaller than regions, states, or nations) is important in order to reduce the vulnerability of human societies to floods (Li \& Landry, 2018). Floods do not just occur at the micro or household level; larger scales matter for floods and flood risk. Externalities from land-use decisions that can affect others' flood risks (e.g., developing natural infrastructure like wetlands, expanding impervious surfaces) and incentives to free-ride on public infrastructure provision (e.g., information provision, open-space preservation, drainage systems, levees) imply that individual-level decision-making can lead to socially suboptimal flood management. Individual or firm decisions to develop wetlands or add impervious surfaces (Kousky \& Zeckhauser, 2006), reduce tree cover (Pramova et al., 2012), install non-levees embankments (Olson \& Morton, 2013), or develop barrier islands and coastal dunes (Reddy, 2000) can cumulate and affect others' flood risks (Kousky, 2010). Left to laissez-faire individual decision-making, many larger infrastructure projects face public goods problems (Greaves \& Penning-Rowsell, 2016; Li \& Landry, 2018; Reddy, 2000) that make optimal provision a challenge. Accordingly, some local governments engage in various flood-risk management activities to overcome collective-action problems in providing infrastructure and addressing externalities. Although, some studies have examined flood management at a meso-level like the community scale (e.g., Brody, Zahran, Highfield, Bernhardt, \& Vedlitz, 2009; Sadiq \& Noonan, 2015a, 2015b), these studies do not analyze the impact of a flood-risk management policy on migration and development.

We address this lacuna by studying the impact of the Community Ratings System (CRS), a federal program (implemented at the city or county scale to induce flood-risk management), on migration and development. There is ample reason to be concerned about migration and development in high-risk areas, and the extent to which public policies exacerbate this. For example, in the U.S., the National Flood Insurance Program (NFIP) is often criticized for encouraging risky and ecologically harmful development in floodplains, thus leading to increased flood disaster impacts (e.g., Bagstad, Stapleton, \& D'Agostino, 2007; Burby, 2001; Chakraborty, Collins, Montgomery, \& Grineski, 2014; Cordes \& Yezer, 1998; Thomas \&

\footnotetext{
${ }^{1}$ Victims include those killed, presumed dead, missing, injured, homeless, or requiring immediate assistance.
} 
Leichenko, 2011). Similarly, in Brazil, Sant'Anna's (2018) study found that government policies could exacerbate disaster impacts.

In order to stem the destruction engendered by flood events, the United States government created the CRS program in 1990 to enable communities to surpass the expectations of the NFIP and voluntarily reduce flood risks (Federal Emergency Management Agency (FEMA), 2017). In return, participating communities receive discounted flood insurance premiums (FEMA, 2017). Although inducing community-level flood-management actions is a first-order objective of the CRS, the second-order effects on economic activity like migration and development are crucial to fully assessing the net effects of the CRS. Despite the myriad studies on the CRS - the determinants of community participation in the CRS (Landry \& $\mathrm{Li}, 2012$; Noonan, Richardson, \& Sadiq, 2018; Sadiq \& Noonan, 2015a), the use of the CRS as a measure of adaptive capacity of municipal leaders to engage in collective action (Posey, 2009), policy learning (Brody et al., 2009), the characteristics of communities that are behaving strategically to take advantage of the incentive structure of the CRS (Sadiq \& Noonan, 2015b), the effects of the CRS on flood-insurance demand (Dixon, Clancy, Seabury, \& Overton, 2006; Zahran, Weiler, Brody, Lindell, \& Highfield, 2009), and flood-insurance claims (Kousky \& Michel-Kerjan, 2015) - the effect of subsidizing community-level flood management on migration and development patterns remains unstudied. Hence, we address this research gap by analyzing the effects of the CRS on migration and development at the tract level. Using panel data (19702010), we estimate fixed-effects (FE) regressions with robust standard errors clustered by group. The findings will benefit both academics and practitioners, especially those evaluating the effectiveness of the CRS program.

In the following section, we discuss some background information on the CRS, review relevant literature, and our hypotheses. Next, we outline the methodology, including detailed information about the data, and discuss the results. Finally, we conclude by discussing the implications of our results and outlining an agenda for future research on flood-risk management.

\section{Background on the CRS}

Since its inception in 1968, the NFIP has aspired to reduce the impact of flooding on public and private infrastructures, provide affordable insurance to property owners, and promote the development of flood protection activities in communities throughout the United States (FEMA, 2017). The NFIP is an initiative between federal and state governments, private insurance companies, and local communities with the goal of reducing flood disasters by enacting and enforcing floodplain-management activities in flood-prone areas (Dixon et al., 2006). According to the Department of Homeland Security (2013), the NFIP reduces floodrelated disaster cost by $\$ 1.7$ billion annually. Despite this reduction, disaster cost is on the increase (Noonan \& Sadiq, 2018). To reduce further the impacts and costs of flood disasters, FEMA implemented the CRS in 1990 to allow communities to implement flood reduction measures beyond what is required under the NFIP (FEMA, 2017). Indeed, the CRS is a voluntary program designed to incentivize communities - cities or counties - to engage in additional floodmanagement activities in order to stem the rising costs of flood disasters. The three goals of the CRS are to reduce flood damage to insurable property, strengthen and support the insurance aspects of the NFIP, and foster comprehensive floodplain management (FEMA, 2017). When communities develop flood-management activities that reflect these three goals, they are able to accumulate credit points and enjoy discounted flood-insurance premiums commensurate with 
their total credit score (Roth \& Kunreuther, 1998). As of May 2016, 1,391 communities were participating in the CRS, representing about $5 \%$ of NFIP participating communities (FEMA, 2016).

Communities participating in the CRS are organized into 10 classes based on their credit points (FEMA, 2017). Class 10 represents communities that do not participate or do not have the minimum number of credit points needed to enter the program. Class 1 represents communities with exceptional floodplain management activities who enjoy a $45 \%$ discount on flood insurance premiums if the community is in a Special Flood Hazard Area (SFHA) - a land area with a 1\% or greater chance of flooding within any given year (FEMA, 2015). Under the NFIP, SFHAs are required to enact floodplain management activities and purchase flood insurance (FEMA, 2015). Communities in the intermediate classes receive discounted flood insurance premiums within SFHAs in increments of 5\%. In other words, a Class 9 community receives a 5\% discount, a Class 8 community receives a $10 \%$ discount and so on until a community reaches a Class 1 receiving the $45 \%$ discount. CRS makes much smaller discounts (5-10\%) on flood-insurance premiums available outside of SFHAs within participating communities.

Credit points depend on a community's ability to implement any of the 20 creditable activities that advance the CRS's goals. These activities span four categories: public information, mapping and regulations, flood damage reduction, and warning and response (FEMA, 2017). This wide array of creditable flood management efforts ranges from information provision (e.g., hazard disclosure, flood insurance promotion) to planning (e.g., watershed master planning) to stricter regulation (e.g., building codes, zoning) to physical infrastructure provision (e.g., retrofitting buildings, structural flood-control projects, building levees). Similarly, maximum possible points awarded in each activity vary widely. Regulations and open-space preservation account for a third of the possible points, whereas $38 \%$ of possible points can be earned for damage reduction activities. Points for levees and dams are small, amounting to less than half the available points for public information activities (7\% of total points available). Communities prefer some activities to others. For example, some activities (e.g., elevation certificates, outreach projects, flood protection information, higher regulatory standards) are undertaken by over $90 \%$ of participating communities, while others (e.g., flood insurance promotion, levees, dams) record no credits earned by any community. See FEMA (2017) for more details on the CRS.

\section{Literature Review}

Few studies have examined the extent to which flood risks and flood-management efforts influence housing development in the U.S. Burby (2001) argues that while flood-insurance programs have only had a limited effect on directing development to locations outside of a floodplain, the NFIP standards have significantly reduced flood losses on new construction located in floodplains. Using Hurricane Katrina as a case study, Burby (2006) contends that federal policies such as the Disaster Mitigation Act of 2000 and the Flood Insurance Act of 1994 and 2004 have attempted to make hazardous areas safer by investing in structural mitigation (e.g., dams, levees) and non-structural mitigation (e.g., flood insurance) measures. Contrarily, these federal programs have facilitated development in hazardous areas, which has, in turn, substantially increased the potential for catastrophic losses (Burby, 2006). Cordes and Yezer (1998) and then later Browne, Dehring, Eckles, and Lastrapes (2015) investigate the effect of NFIP participation on local housing development. Cordes and Yezer (1998) find that increased 
growth in beachfront communities is not because of government investment in shore protection measures, but due to increased income and employment in inland communities. Browne, Dehring, Eckles, and Lastrapes's (2015) study finds that participating in the NFIP leads to increases in housing starts and permits in inland counties and a decrease in housing starts and permits in coastal counties with average flood zone acreage.

In addition to location of development, the type of housing and mitigation investments may be affected by flood risk and management programs. Mobile-home residents, for instance, are less likely to purchase flood insurance along the Gulf of Mexico and Florida's Atlantic Coast (Petrolia, Landry, \& Coble, 2013). However, they are not statistically different in their likelihood of purchasing wind insurance compared to individuals living in single-family homes (Petrolia et al., 2013). Less has been written on flood-management programs' effects on building construction types. For example, whether the construction type changes because of floodmanagement programs, remains understudied.

The extant research has shown that individuals use migration as a strategy for adapting to climate change and changing local risks. For example, Portnykh (2014) estimates a location choice model to show the importance of migration as a way to adapt to climate change. Boustan, Kahn, and Rhode (2012) study how individuals used migration as a strategy to self-protect from the impacts of natural disasters in the 1920s and 1930s. Their result shows that young men migrated from areas hit by tornadoes and relocated to areas susceptible to floods. Furthermore, Hornbeck and Naidu (2014) examine the impact of the Great Mississippi Flood of 1927 on outmigration of the black population. They find immediate and persistent out-migration of blacks in flooded counties. In addition, Husby, Groot, Hofkes, and Dröes (2014) evaluate a flood from the 1950s to show populations shift in response to new flood/disaster risks. Yet, how government flood management programs like the CRS affect migration and relocation remains unclear. Studies of the CRS, like Li and Landry (2014), and Zahran, Brody, Highfield, and Vedlitz (2010), show how population levels correlate with CRS participation rather than how CRS alters population growth patterns. Similarly, Sadiq and Noonan (2015a) find that counties joining the CRS tend to have greater shares of residents moving in years prior. However, they do not examine the effects on relocation tendencies after joining the CRS, nor do they allow for heterogeneity in migration patterns within counties.

This study raises the question of whether the CRS attracts more development to or drive development away from flood risk. The CRS may theoretically both push and pull local development, leaving the theoretically ambiguous result a matter of empirical assessment. On the one hand, the CRS produces additional flood risk information. The vast environmental information disclosure literature (Beierle, 2004) proposes that when individuals or communities are aware of environmental risks, they are more likely to make better and safer decisions. For example, Finger and Gamper-Rabindran's (2013) find that mandatory pollution disclosure programs may be responsible for reducing workers' chemical exposure. Beierle (2004) maintains that information disclosure programs are fundamentally implemented with the goal of changing behavior. This view is germane to the CRS because the CRS is partly an information-based policy: eight out of 20 creditable activities under the CRS are related to public information. Public information activities are supposed to encourage individuals within CRS participating communities to make better decisions. For example, knowing that a particular home is located in a floodplain might change the mind of a prospective home buyer from buying that particular home. Furthermore, the CRS encourages stricter building regulations and community restrictions on locations and types of new construction (Browne et al., 2015). Once better informed and 
facing costlier housing, households may "head for the hills" and away from risky settlements. Thus, we offer the following hypotheses.

On the other hand, CRS incentives may encourage more development or at least discourage departures. There is ample evidence suggesting that community risk mitigation programs such as the CRS can be successful at reducing community flood risk (e.g., Sadiq \& Noonan, 2015a, 2015b) and future property damage (Brody, Zahran, Maghelal, Grover, \& Highfield, 2007; Brody, Zahran, Highfield, Grover, \& Vedlitz, 2008). If such programs are not properly designed, however, they can create perverse incentives that could undermine the intended programmatic benefits (Sadiq \& Noonan, 2015b; Zahran et al., 2010). Moreover, there is evidence that poorly designed flood risk programs actually encourage development of homes in flood-prone areas. Burby (2001) notes that within 30 years of passing the NFIP, development within 100-year floodplains rose by 53\%. Chakraborty et al. (2014) suggest that flood subsidies heightened housing development in flood-prone coastal communities. In addition, Bagstad et al. (2007) argue that the NFIP has encouraged development in flood zones by providing subsidies to community members. In short, subsidizing development in flood-prone areas can lead to perverse outcomes, especially if flood-insurance premiums are not commensurate with the inherent flood risk (Burby, 2001). The CRS increases subsidies for flood insurance in SFHAs. Thus, the hypotheses below might plausibly be rejected depending on which influence of the CRS is stronger: its "scarecrow" effects of discouraging development in high-risk areas, or its subsidy effects of encouraging development in high-risk areas.

H1a: Tracts in CRS communities have less new housing construction (or population growth) than non-CRS tracts.

H1b: Tracts in CRS communities have more new housing construction (or population growth) than non-CRS tracts.

H2a: Tracts in CRS communities have fewer mobile homes or trailers than non-CRS tracts.

$\mathrm{H} 2 \mathrm{~b}$ : Tracts in CRS communities have more mobile homes or trailers than non-CRS tracts.

H3a: Tracts in CRS communities have more non-movers than non-CRS tracts.

H3b: Tracts in CRS communities have fewer non-movers than non-CRS tracts.

Finally, the literature provides the empirical justification for relevant variables to include in the analysis. The idea is to control for variables that might make a community join the CRS and affect migration or development. Control variables include the tract-level poverty rate and unemployment rate. Indicators like these may correlate with CRS participation (Li \& Landry, 2014; Posey, 2009) while also affecting subsequent migration and development in the tract. Controls for vacancy rates, rentership rates, and mean housing values capture the conditions of the tract's housing stock. Sadiq and Noonan (2015a) find housing values and homeownership rates to be positive and significant predictors of CRS participation. Likewise, Bollens, Kaiser, and Burby (1989) find a positive correlation between cities' housing values and floodplain programs. The share of the county that lived in the same house five years prior also helps control for rapidly transitioning markets. 


\section{Methodology}

To explore the drivers of migration and development, a straightforward and parsimonious model is estimated for a national panel of tract-level observations over several decades (19702010). The empirical models estimate factors influencing several alternative measures of migration and development, with the same basic specification shared across each of the alternative dependent variables. The panel data allow an estimation of a fixed-effects regression model with robust standard errors clustered by group, where "group" in this context refers to the census tract as our local unit of observation. Our analysis addresses the concern over possible endogeneity issues in three ways. First, we use a fixed-effect model to help control for any timeinvariant unobservable factors that might lead to endogeneity. Second, our unit of analysis is tract-level and the policy treatment is at the community-level. Our argument is that individual tracts lack 'market power' and cannot influence the local jurisdiction's adoption choice - the decision to participate or not to participate in the CRS can only be made at the county or city level. Moreover, the average CRS community contains 190 tracts. Finally, we control for a host of time-varying attributes such as poverty rates that might affect migration or development.

The empirical model thus takes the form:

$$
y_{i t}=\alpha+\beta C R S_{i t}+\delta \text { Damage }_{i t}+\rho \text { Risk }_{i}+\gamma\left(C R S_{i t} \times \text { Risk }_{i}\right)+\sigma X_{i t-10}+\tau_{t}+\mu_{i}+\varepsilon_{i t}
$$

Where $i$ indexes tracts, and $t$ indexes census years (1980,1990, 2000, 2010). The variable $y$ measures population and housing outcomes. $C R S$ is the variable of interest, a dummy variable reflecting whether the tract was in a community participating in the CRS in year $t$. The vector $X$ includes tract-level socioeconomic controls, all lagged by ten years. The vectors Risk and Damage describe flood risks and recent flood property damage, respectively. Notably, the Risk vector contains time-invariant measures, although its interaction term with $C R S$ remains timevarying. Year effects $(\tau)$, estimated as coefficients of year dummy variables, and tract-level fixed effects $(\mu)$ are also in the model, in addition to the white-noise error term $(\varepsilon)$. The presence of tract fixed-effects leaves $\rho$ unidentified, and the model to be estimated becomes:

$$
y_{i t}=\alpha+\beta C R S_{i t}+\delta \text { Damage }_{i t}+\gamma\left(C R S_{i t} \times \text { Risk }_{i}\right)+\sigma X_{i t-10}+\tau_{t}+\mu_{i}+\varepsilon_{i t}
$$

\subsection{Data}

In order to examine the impact of the CRS on migration and development, we merged five different data sources together (see Table 1). The first data source is CRS participation from FEMA from 2000 and 2010. The data contain information about participating communities such as name, place, and year of participation. The second data source is the Neighborhood Change Database (NCDB) from Geolytics, Inc., which contains US Census information. This study uses census information at the census tract level, normalized to use time-consistent 2010 tract boundaries, for the decadal years from 1970 to 2010 (i.e., 1970, 1980, 1990, 2000, and 2010). The NCDB contains information such as population, household income, housing characteristics, poverty status, employment, and housing values. 


\section{Table 1}

Data sources.

\begin{tabular}{|c|c|c|c|}
\hline Data & Unit & Years & Available Information \\
\hline $\begin{array}{l}\text { 1. CRS Participation from } \\
\text { FEMA (2017) }\end{array}$ & Place/County & 2000,2010 & $\begin{array}{l}\text { Name of participant } \\
\text { community, } \\
\text { CRS class, credits earned, etc. }\end{array}$ \\
\hline $\begin{array}{l}\text { 2. Neighborhood Change } \\
\text { Database (NCDB) from } \\
\text { Geolytics, Inc. }\end{array}$ & Tract & $\begin{array}{l}1970-2010, \\
\text { for census } \\
\text { years }\end{array}$ & $\begin{array}{l}\text { Housing values, vacant } \\
\text { housing, } \\
\text { renters, non-migrants, etc. }\end{array}$ \\
\hline $\begin{array}{l}\text { 3. The Spatial Hazard Events } \\
\text { and Loss Database for the } \\
\text { United States (SHELDUS) }\end{array}$ & County & $1975-2010$ & $\begin{array}{l}\text { Hazard type, damages, injuries, } \\
\text { fatalities, etc. }\end{array}$ \\
\hline $\begin{array}{l}\text { 4. Flood Insurance Rate Maps } \\
\text { from FEMA (2015) }\end{array}$ & Flood zones & Current & $\begin{array}{l}\text { Base flood elevations, flood } \\
\text { zones, floodplain boundaries, } \\
\text { etc. }\end{array}$ \\
\hline $\begin{array}{l}\text { 5. Flood risk data from the } \\
\text { United States Department of } \\
\text { Transportation (US DOT) }\end{array}$ & $\begin{array}{l}1 \mathrm{~km} \times 1 \mathrm{~km} \\
\text { raster map, } \\
\text { converted to } \\
\text { census tract }\end{array}$ & 1996 & $\begin{array}{l}\text { Index value/minimum, } \\
\text { maximum, mean by tract, etc. }\end{array}$ \\
\hline
\end{tabular}

The third data source is Spatial Hazard Events and Losses Database for the United States (SHELDUS), which contains monthly flood damage data. SHELDUS contains county-level information to include location and date of hazard event, number of fatalities, property losses, injuries, etc. Although, this information is available for 18 different natural hazards, we use information on flood hazard only in the analyses. We assume that flood damages are distributed proportional to population among the tracts in a particular county. This assumption follows from the similarity in flood insurance claim rates (the share of policies that make a claim in a given year) occurring inside SFHAs versus outside (Kousky \& Michel-Kerjan 2015). The fourth data source is the latest Flood Insurance Rate Maps (FIRMS). The FIRMS provide tract-level information about SFHAs and the risk premium zones for $87 \%$ of the United States. The fifth data source is flood risk (raster) data from the United States Department of Transportation (US DOT) (1996). The information contained in the flood risk data is of very high resolution (1 km grid cell) and based on a ranking of flood risk (on a 0-100 scale) by FEMA as part of a study to assess the risks to pipelines from natural disasters including flooding. ${ }^{2}$

\footnotetext{
${ }^{2}$ The USDOT flood risk data are converted from a $1 \mathrm{~km}$ by $1 \mathrm{~km}$ grid cell map onto census block groups, taking the mean value of the flood risk metric across the cells in each block group. Then, each census tract takes the mean value of these block groups' flood risk value. This mean-mean aggregation function was just one of many alternatives tried (e.g., min-max, max-max, max-mean). The basic findings are not very sensitive to the aggregation choice. The mean-mean approach is used here as it is the most straightforward. See the full report (US DOT 1996) for more details.
} 
Table 2

Variables and Their Descriptions.

\begin{tabular}{|c|c|c|}
\hline Variable & Description & Data Source \\
\hline \multicolumn{3}{|l|}{ Dependent (Development) } \\
\hline New construction & $\begin{array}{l}\text { Share of houses built in the last five } \\
\text { years in a tract }\end{array}$ & NCDB (Geolytics) \\
\hline Mobile homes or trailers & $\begin{array}{l}\text { Percent housing units in a tract that are } \\
\text { mobile homes or trailers }\end{array}$ & NCDB (Geolytics) \\
\hline \multicolumn{3}{|l|}{ Dependent (Migration) } \\
\hline Population growth & $\begin{array}{l}\text { Population of a tract } / \text { population of a } \\
\text { tract }_{\mathrm{t}-10}\end{array}$ & NCDB (Geolytics) \\
\hline Non-movers & $\begin{array}{l}\text { Proportion of residents in the same } \\
\text { house five years prior in a tract }\end{array}$ & NCDB (Geolytics) \\
\hline \multicolumn{3}{|l|}{ Independent Variables } \\
\hline CRS participation & $\begin{array}{l}\text { Dummy variable indicating tract } \\
\text { resides in a community participating in } \\
\text { the CRS }\end{array}$ & FEMA (2017) \\
\hline Flood risk in CRS communities & CRS participation $*$ Flood risk & $\begin{array}{l}\text { FEMA (2017) and US } \\
\text { DOT }\end{array}$ \\
\hline $\begin{array}{l}\text { Flood zones in CRS } \\
\text { communities }\end{array}$ & $\begin{array}{l}\text { CRS participation * SFHA share (share } \\
\text { of a tract in a Special Flood Hazard } \\
\text { Area) }\end{array}$ & $\begin{array}{l}\text { FEMA (2017) and FEMA } \\
\text { (2015) }\end{array}$ \\
\hline Property damage per capita & $\begin{array}{l}\text { Total county flood damages within the } \\
\text { previous five years/County population }\end{array}$ & SHELDUS \\
\hline No flood prior & $\begin{array}{l}\text { Dummy variable indicating the tract } \\
\text { lacked a flooding event within the } \\
\text { previous five years }\end{array}$ & SHELDUS \\
\hline \multicolumn{3}{|l|}{ Control Variables } \\
\hline Poverty rate (lag) & Tract poverty rate (10-year lag) & NCDB (Geolytics) \\
\hline Mean housing value (lag) & $\begin{array}{l}\text { Log of mean housing value in a tract } \\
\text { (10-year lag) }\end{array}$ & NCDB (Geolytics) \\
\hline Population density (lag) & $\begin{array}{l}\text { Total tract population divided by total } \\
\text { land area (10-year lag) }\end{array}$ & NCDB (Geolytics) \\
\hline County non-movers (lag) & $\begin{array}{l}\text { Proportion of persons residing in the } \\
\text { same county five years ago ( } 10 \text {-year } \\
\text { lag) }\end{array}$ & NCDB (Geolytics) \\
\hline Unemployment rate (lag) & $\begin{array}{l}\text { Number of unemployed divided by } \\
\text { total number in the labor force in a } \\
\text { tract (10-year lag) }\end{array}$ & NCDB (Geolytics) \\
\hline Renters (lag) & $\begin{array}{l}\text { Share of total housing units that are } \\
\text { renter occupied in a tract (10-year lag) }\end{array}$ & NCDB (Geolytics) \\
\hline Vacant homes (lag) & $\begin{array}{l}\text { Share of total housing units that are } \\
\text { vacant in a tract (10-year lag) }\end{array}$ & NCDB (Geolytics) \\
\hline
\end{tabular}

Note: All variables listed here enter the model at the tract level for year $t$, where $t=1980,1990,2000$, and 2010. Some variables are measured in year $t$ (e.g., CRS participation, all dependent variables). Flood event variables are measured using the previous five years (i.e., year $t-5$ through year $t$ ). All 'Control variables' are measured at year $t$ 10 (i.e., with a ten-year lag). Thus, the control variables range in years from 1970-2000. Time invariant flood-related variables Flood risk and SFHA share are described in the text.

\subsection{Variables}


The dependent variables of interest are development and migration (see Table 2). Development is measured in two ways: (1) New construction - share of houses built in the last five years, and (2) Mobile homes or trailers - share of housing units in a tract that are mobile homes or trailers. Both variables are calculated using housing variables that the decennial Census reports by simply dividing the count of the appropriate type of housing by all housing units in the tract. Similarly, we employ two measures of migration: (1) Population growth -Population of a tract $/$ population of a tract $t_{-10}$, and (2) Non-movers - proportion of residents in the same house 5 years prior in a tract. This latter variable is a measure directly reported in the decennial census.

The analyses focus on the following independent variables: CRS participation, flood risk, flood risk in CRS communities, flood zones in CRS communities, property damage, and no flood prior. There are two options available with regard to CRS participation - communities are either participating or not participating in the CRS program. Those participating in the CRS in a given census year are coded 1, and 0 otherwise. Flood risk is measured as the mean flood risk from $1 \mathrm{~km}$ grid cells within a tract. The variable, flood risk, is omitted because it is time-invariant. Flood risk in CRS communities is the interaction term between Flood risk and CRS participation. This variable represents flood risk tracts in CRS-participating communities. The SFHA share represents the spatial extent of high-risk flood zones overlaying the tract for all tracts in the US for which digital FIRMs are available. Next, Flood zones in CRS communities is obtained by interacting CRS participation with SFHA share. This variable measures the percent of the tract's area covered by high-risk flood zones for tracts in CRS communities (coded 1; 0 otherwise). Although SFHA share is time invariant in these data, its interaction with CRS participation captures a differential effect of a tract's 100-year floodplain exposure for tracts within CRS communities, which does vary over time. The benefit of including both CRS participation*Flood risk and CRS participation*SFHA share is to be able to distinguish between the richer, more continuous measure of flood risk (Flood Risk) and the more limited (Brody, Blessing, Sebastian, $\&$ Bedient, 2012) binary notion of flood risk that maps directly onto flood insurance requirements and CRS discounts. Using only one would further mix risk and insurance or policy effects, while including both allows us to differentiate between extant flood risk and officially regulated flood zones. Thus, although the main effect of the $C R S$ indicates the average effect of CRS participation across the community irrespective of the tract's flood risks, the interaction terms pick up whether CRS participation is different in tracts that are more in floodplains or have greater flood risks. Property damage per capita is measured as the total flood damage in a county over the previous five years divided by the county population. No flood prior is measured as the absence of at least one flooding event in a tract within the last five years. Thus, both flood event and damage variables draw from the detailed SHELDUS data from the previous five years (e.g., 1985-1990 for $t=1990)$.

To isolate the effect of the independent variables on the dependent variables, we include the following control variables: poverty rate, mean housing value, population density, county non-movers, unemployment rate, renters, and vacant homes. Poverty rate is measured as the tract poverty rate. Mean housing value is measured as the log of mean housing value in a tract. We measure population density as the total tract population divided by total land area. County nonmovers is the proportion of persons residing in the same county five years ago. Furthermore, unemployment rate is measured as the number of unemployed divided by total number in the 
labor force. Renters is the share of total housing units that are rentals, and vacant is measured as the share of total housing units that are vacant. All these control variables enter as lagged to the previous census year (i.e., a 10-year lag) in order to avoid simultaneity concerns. Although we drop $13 \%$ of all tracts due to missing FIRM data, missing values for socioeconomic controls like unemployment rate and housing value further reduce the sample size. The FE regressions use 62,537 tracts, or almost $86 \%$ of all 2010 tracts, with FIRMs and when they have nonmissing NCDB data. ${ }^{3}$

\section{Results}

We discuss a few notable descriptive statistics presented in Table 3. On average, about $10 \%$ of homes are new construction, $6 \%$ are mobile homes or trailers, and $61 \%$ of the population are non-movers. In any given census year, approximately $10 \%$ of tracts are participating in the CRS, a figure that rises to $17.8 \%$ if the sample is restricted to 2000 and 2010 after the CRS program began. The average mean risk for all the tracts is about 42 on a scale of $0-100$. Tracts average about $12 \%$ of their area being in a SFHA. In addition, about $16 \%$ of tracts in a county have not experienced a flood within the last five years. The mean unemployment rate is approximately $6 \%, 31 \%$ of residents are renters, and $8 \%$ of homes are vacant.

\section{Table 3}

Descriptive Statistics.

\begin{tabular}{|l|l|l|l|l|l|}
\hline Variable & N & Mean & Std. Dev. & Min & Max $^{\mathbf{4}}$ \\
\hline Dependent Variables & 216,984 & 0.103 & 0.141 & 0 & 1 \\
\hline New construction & 216,984 & 0.063 & 0.111 & 0 & 1 \\
\hline Mobile homes or trailers & 216,979 & 1.864 & 27.450 & 0 & 4,758 \\
\hline Population growth & 216,899 & 0.611 & 0.198 & 0 & 1 \\
\hline Non-movers & \begin{tabular}{l}
$|l|$ \\
\hline Independent Variables
\end{tabular} \\
\hline CRS participation & 216,984 & 0.102 & 0.302 & 0 & 1 \\
\hline Flood risk in CRS communities & 216,984 & 3.960 & 14.764 & 0 & 99 \\
\hline Flood risk & 216,984 & 41.914 & 27.636 & 0 & 99 \\
\hline
\end{tabular}

${ }^{3}$ To examine the sensitivity of the results to dropping tracts without digital FIRM data available, multiple imputation regression techniques are applied to the four models in Table 4. Using variables in Table 2 and especially information from the raster flood hazard maps (which cover all tracts) to impute CRS participation*SFHA share over 20 imputations, the estimates in Table 4 can be compared to results where the SFHA share variable is imputed and no longer missing for a sizeable portion of the country. The full results, available on request, show minimal change to the coefficients of interest and even to the SFHA share coefficient. The only exception is for the $C R S$ participation*Flood risk parameter, which becomes marginally insignificant in the new construction model.

${ }^{4}$ The decennial census uses tract boundaries that change every decade. In order to keep our units of analysis constant through the five decades examined in this study, we use the NCDB, for which Geolytics has reestimated Census variables from previous census years to match them to the 2010 tract boundaries. While the NCDB offers a key advantage of normalizing Census data so that our geographic units of analysis are fixed through time, their estimation process can result in some percentage or share variables exceeding 1.0 (especially for much older data, such as 1970, when the whole country was not yet mapped to Census tracts). In our sample, four tract-years have estimated values for Renters or Vacant homes that exceed unity in the NCDB. Similarly, Geolytics imputation and estimation processes to create the NCDB is also the reason for the unusual descriptive statistics for the population growth variable. The median of Population growth is 1.065 . 


\begin{tabular}{|l|l|l|l|l|l|}
\hline Flood zones in CRS communities & 216,984 & 0.014 & 0.081 & 0 & 1 \\
\hline SFHA share & 216,984 & 0.116 & 0.186 & 0 & 1 \\
\hline Control Variables & 216,984 & 51.300 & 906.411 & 0 & $66,208.33$ \\
\hline Property damage (\$) & 216,984 & 0.155 & 0.362 & 0 & 1 \\
\hline No flood prior & 216,984 & 0.120 & 0.105 & 0 & 1 \\
\hline Poverty rate & 216,984 & 10.934 & 1.047 & -7.099 & 14.174 \\
\hline Mean housing value (\$) & 216,984 & 0.002 & 0.004 & 0 & 0.082 \\
\hline Population density & 216,984 & 0.769 & 0.139 & 0 & 1 \\
\hline County non-movers & 216,984 & 0.060 & 0.047 & 0 & 1 \\
\hline Unemployment rate & 216,984 & 0.309 & 0.204 & 0 & 2 \\
\hline Renters & 216,984 & 0.078 & 0.081 & 0 & 1.5 \\
\hline Vacant homes & & & & \\
\hline
\end{tabular}

Table 4 presents the results of four tract-level FE models for new construction, mobile homes or trailers, population growth, and non-movers. The results of the new construction model indicate a negative and significant relationship between new construction and CRS participation. Specifically, there is a $1.8 \%$ decrease in new construction in CRS tracts holding all other variables constant. Similarly, there is a significant and negative relationship between new construction and flood risk in CRS communities. On the contrary, there is a significant and positive relationship between new construction and flood zones in CRS communities. In addition, there is a positive and significant relationship between new construction and property damage as well as between new construction and no flood prior.

A look at the mobile homes or trailers model shows a negative and significant relationship between CRS participation and the construction of mobile homes or trailers. The relationships between construction of mobile homes or trailers and flood risk in CRS communities, flood zones in CRS communities, property damage, and no flood prior are all insignificant.

According to the population growth model, there is a negative and significant association between participating in the CRS and population growth. Similarly, there is a negative and significant relationship between flood zones in CRS participating communities and population growth. These results are contrary to that of flood risk in CRS communities, which indicates a positive and significant association with population growth. Further, there is a positive and significant relationship between population growth and property damage, and a negative and significant association between population growth and no flood prior.

Finally, the results of the non-movers model indicate a 2.6 percentage-point increase in the proportion of non-movers in CRS tracts holding all other variables constant. Further examination into this model's results shows a negative and significant relationships between non-movers and the following three variables; flood risk in CRS communities, property damage, and no flood prior. The relationship between non-movers and flood zones in CRS communities is negative and insignificant. 
Table 4

Fixed-Effects Regression Results for New construction, Mobile homes or trailers, Population growth, and Non-movers.

\begin{tabular}{|c|c|c|c|c|}
\hline 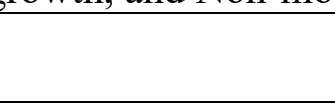 & $\begin{array}{l}\text { New } \\
\text { construction }\end{array}$ & $\begin{array}{l}\text { Mobile homes } \\
\text { or trailers }\end{array}$ & $\begin{array}{l}\text { Population } \\
\text { growth }\end{array}$ & Non-movers \\
\hline Variable & Coeff. & Coeff. & Coeff. & Coeff. \\
\hline CRS participation & $-0.018 * * *$ & $-0.005 * * *$ & $-2.754 * * *$ & $0.026 * * *$ \\
\hline $\begin{array}{l}\text { Flood risk in CRS } \\
\text { communities }\end{array}$ & $-0.0001 * *$ & -0.00002 & $0.039 * * *$ & $-0.0001 * * *$ \\
\hline $\begin{array}{l}\text { Flood zones in CRS } \\
\text { communities }\end{array}$ & $0.012 * *$ & -0.004 & $-1.740 *$ & -0.006 \\
\hline Property damage & $5.378 \mathrm{e}-07 * * *$ & $-4.662 e-09$ & $0.0001 * * *$ & $-5.224 \mathrm{e}-07 * * *$ \\
\hline No flood prior & $0.003 * * *$ & 0.0001 & $-0.896 * * *$ & $-0.009 * * *$ \\
\hline Poverty rate & $0.357 * * *$ & $0.018 * * *$ & $13.102 *$ & $-0.047 * * *$ \\
\hline Mean housing value & $-0.004 * * *$ & $-0.008 * * *$ & $4.373 * * *$ & $0.010 * * *$ \\
\hline Population density & $-28.573 * * *$ & $-0.957 * * *$ & 128.506 & $26.646 * * *$ \\
\hline County non-movers & 0.002 & -0.001 & $20.420 * * *$ & $0.089 * * *$ \\
\hline Unemployment rate & $0.113 * * *$ & $0.059 * * *$ & $146.941 * * *$ & $-0.041 * * *$ \\
\hline Renters & $-0.139 * * *$ & $-0.026 * * *$ & $33.268 * * *$ & $-0.033 * * *$ \\
\hline Vacant homes & $0.093 * * *$ & $-0.025 * * *$ & $95.773 * * *$ & $-0.251 * * *$ \\
\hline 1980 & $0.130 * * *$ & $0.005 * * *$ & $9.186 * * *$ & $-0.317 * * *$ \\
\hline 1990 & $0.086 * * *$ & $0.012 * * *$ & $1.429 * * *$ & $-0.309 * * *$ \\
\hline 2000 & $0.059 * * *$ & $0.010 * * *$ & $-0.922 * * *$ & $-0.293 * * *$ \\
\hline 2010 & Omitted & Omitted & Omitted & Omitted \\
\hline $\begin{array}{l}\mathrm{N} \\
\mathrm{F}\end{array}$ & $\begin{array}{l}216,984 \\
31112\end{array}$ & $\begin{array}{l}216,984 \\
273,1\end{array}$ & $\begin{array}{l}216,979 \\
106\end{array}$ & $\begin{array}{l}216,899 \\
43,2539\end{array}$ \\
\hline (p-value) & $\mathrm{p}<0.0001$ & $\mathrm{p}<0.0001$ & $\mathrm{p}<0.0001$ & $\mathrm{p}<0.0001$ \\
\hline Adjusted R-Squared & 0.298 & 0.034 & 0.079 & 0.818 \\
\hline
\end{tabular}

Note: ${ }^{*} \mathrm{p}<.1, * * \mathrm{p}<.05, * * * \mathrm{p}<.01$

\section{Discussion}

Our analyses take advantage of two features of the empirical setting to identify policy effects of the CRS program on migration and development. This is particularly important for a program like the CRS, where participation is voluntary and endogeneity may weaken the results. First, we take advantage of natural and exogenous measures of flood risk as well as detailed historical records of local flood damage. Second, we construct a panel of census tracts nationwide that includes participating and non-participating CRS communities, including those that joined the program recently. Roughly speaking, this approach allows us to examine changes in migration and housing development trends across CRS participants and non-participants.

We now focus our attention to discussing the results of the four models. With regard to the impact of CRS participation on new housing development, the results of the new construction model suggest that there is a decrease in the share of new construction of houses in tracts located in CRS participating communities in comparison to the same tracts prior to joining the CRS. This 
result provides empirical evidence in support of Hypothesis 1a, and is supported by the environmental information disclosure literature (Beierle, 2004; Finger \& Gamper-Rabindran, 2013). Similarly, flood-prone tracts within CRS participating communities also experienced even lower new housing construction in comparison to those same flood-prone tracts before they joined the CRS. Contrary to the two previous results, flood zones within CRS tracts seem to attract new construction of houses. This finding is corroborated by several previous studies (e.g., Bagstad et al., 2007; Burby, 2001; Chakraborty et al., 2014; Cordes \& Yezer, 1998). This increase in new housing construction in flood zones may be the result of the availability of higher flood insurance discounts for SFHAs relative to CRS tracts outside of SFHAs (Chakraborty et al., 2014). This study is unable to ascertain whether these new houses in the floodplain are elevated in compliance with the NFIP requirements or not. Calculated at mean values, the effect of $C R S$ participation is a 1.85 percentage point reduction in the new construction share. This effect remains negative (-0.0064) even for a tract completely within an SFHA, and would grow to a 2.70 percentage point reduction in new construction share for tracts with Flood Risk of 99 (and SFHA share at the mean). The offsetting effects of extant flood risk and official flood zones in CRS communities suggests nuanced pressures on new construction, with perhaps the new construction more likely in low-risk areas with some proximity to (better managed due to CRS participation) flood zones.

With regards to property damage, the more property damage from floods, the higher the share of new construction. Similarly, there is a positive relationship between the fact that there was no flooding event within the previous five years and the share of new construction. In other words, the share of new housing construction increases with more property damage and with more years without a flood. The effect is modest, with a standard deviation increase in Property damage associated with a 0.1 percentage point increase in the share of new construction in a tract. These results make sense in the context of the earlier result that shows an increase in new construction of houses in flood zones in CRS communities. One would expect to see an increase in new housing development after a disaster as the community moves to rebuild completely destroyed homes. Furthermore, it is expected that a community would build new homes in areas that have not experienced a flood within the last five years. The implication of this result is that communities might be using a lack of previous flood in an area as an indication that the area is not prone to flooding. This could create a false sense of security if a community's decision to build in an area is solely based on this criterion.

The results of the mobile homes or trailers model indicate that there is less construction of mobile homes or trailers in tracts located in CRS participating communities in comparison to those same tracts prior to joining the CRS. Calculated for a typical tract in the CRS (with mean Flood risk $=38.9$, mean SFHA share $=0.139)$, the effect of CRS participation is a 0.66 percentage point decrease in the share of mobile homes or trailers. These results provide evidence in support of Hypothesis 2a, and suggest that the CRS may be discouraging the construction of mobile homes or trailers within participating communities. This result is also in line with the arguments of proponents of the environmental information disclosure that when a community is aware of environmental risks, it is more likely to make safer and better decisions (Beierle, 2004; Finger \& Gamper-Rabindran, 2013).

According to the population growth model, there is a decrease in population growth rates in tracts located in CRS participating communities in comparison to growth rates prior to joining the CRS. Hence, Hypothesis 1a is supported. Conversely, flood-prone tracts in CRS communities experienced an increase in population growth, while flood zones in CRS communities saw a 
decrease in population growth. These results suggest that the CRS is discouraging population growth in tracts located in CRS participating communities and in flood zones after joining the CRS. The effect of CRS participation, when calculated at average risk values among CRSparticipating tracts, is a -1.46 , a substantially lower growth rate. Yet among higher flood risk tracts (i.e., Flood risk $>76$, when holding SFHA share fixed at 0.139), the CRS effect on population growth can become positive. These results help to accentuate the effect of the CRS on population growth by contrasting the increase in population growth in flood risk areas with the decrease in population growth in floodplains. The implication of this result is that the reduction in population growth in CRS participating communities may be occurring as a result of the CRS preventing people from living in flood-prone areas within those communities. This is what we refer to as the "scarecrow" effect. In doing so, the CRS is helping communities increase their resilience to future flood events-a fundamental goal of the CRS program. In addition, the results show a positive relationship between population growth and recent property damage from flooding. As new construction also increases with recent flooding and property damage, population grows faster with recent damaging floods. There is more new building, and more residents, after these flood disasters. ${ }^{5}$ Finally, the negative relationship between population growth and no flood prior indicates a sharp decline in growth rates in counties avoiding recent flood disasters relative to areas experiencing little flood property damage. This effect is consistent with counties with rarer flood events (i.e., lower density, lower population counties) growing slower. This draws attention to the possibility that the SHELDUS data captures flood disasters and some flood events may not result in damages substantial enough to be recorded in SHELDUS.

With regards to non-movers, tracts within CRS communities are increasing their share of non-movers relative to before joining the CRS. Calculated at average Flood risk and SFHA share in the CRS, the effect of CRS participation is a 2.1 percentage point increase in the share of nonmovers. This result supports Hypothesis 3a, and suggests that if residents of CRS communities are staying more, they may not be able to explore economic opportunities outside of their communities as researchers have found that the higher the proportion of non-movers in a country, the higher the poverty level (e.g., Rupasingha \& Goetz, 2007). Furthermore, another result suggests that the CRS deters non-movers in flood-prone tracts. Taking both results together, it appears that the CRS is encouraging people to stay in tracts located in CRS participating communities in comparison to those same tracts prior to joining the CRS. More importantly, this positive effect of CRS on staying is diminished for households in risky areas within participant communities. (The share of non-movers might typically grow by 2.6 percentage points after joining the CRS for a lower-risk tract, but average non-mover growth is only 1.5 percentage points for the riskiest tract.) The negative relationship between non-movers and property damage suggests that people tend to migrate from an area that is devastated by flood events. This result is consistent with several studies that demonstrated that migration is an

\footnotetext{
${ }^{5}$ Causal interpretations here are complicated by at least two important limitations of the data. First, the population growth variable refers to growth from year $t-10$ to year $t$, while property damage refers to damage from year $t-5$ to year $t$. Growth in those first five years $(t-10$ to $t-5)$ could lead to more property exposed to flood risk and increase the likelihood and expected amount of such a flood disaster. Second, because the property damage from SHELDUS is measured at the county level (and only normalized to the tract-level in per-capita Property damage), it is possible that a severe flood event is concentrated in only a handful of tracts in a particular county. If this displaces population to many nearby tracts within the same county, then population growth will be positive for most observations and negative for a few, while Property damage is positive for all of them. This displacement could give the appearance of a positive Property damage effect because the damage value is available only at the county level.
} 
adaptation mechanism for coping with disasters and climate change (Husby et al., 2014; Kahn, 2015; Portnykh, 2014; Richert, Erdlenbruch, \& Figuieres, 2017). Finally, the negative relationship between non-movers and no flood prior suggests that individuals are migrating from areas that have not experienced a flood event. Tracts in counties experiencing five flood-free years tend to see more residential turnover in those years, perhaps as areas with more sporadic flooding discourage stable populations. It is also plausible that there have been prior floods in such areas, but the damages caused are not substantial enough to be captured by SHELDUS.

\section{Conclusion}

Floods continue to wreak havoc on ecological and human systems (Jonkman, 2005; Sadiq \& Noonan, 2015a). Amid a growing concern of climate change impacts, these systems could be devastated further (Botzen et al., 2009; IPCC, 2013). Understanding and improving flood management at the community scale is important in order to reduce the vulnerability of human societies to floods. Although, researchers have studied flood-risk management policy at the community scale, this literature has largely overlooked analyzing the impact of a flood-risk management policy on migration and development, especially at a refined geographic scale.

This study examines the impact of the CRS on migration and development. The CRS program was created in 1990 to enable communities to voluntarily reduce flood risks, and in return, receive discounted flood insurance premiums. Although reducing flood risk is a primary objective of the CRS, the second-order effects on economic activity like migration and development are crucial to fully assessing the net effects of the CRS on ecological and human systems. Despite the myriad studies on the CRS, the effect of subsidizing community-level flood management on migration and development patterns remains unstudied. Hence, the current study is the first to empirically investigate the effect of the CRS program on migration and development patterns. In general, the results indicate that the CRS discourages new housing developments and the construction of mobile homes or trailers in participating communities. In addition, the CRS discourages population growth, especially in floodplains, as well as migration out of CRS participating communities.

Although, our study provides critical insights on the impact of the CRS program on migration and development, further inquiries are warranted. First, our analyses focused on five Census years, and excluded the years in between Censuses. Future studies should consider including intercensal years in their analyses, which would allow for more short-term adaptations to be detected. Secondly, there are other determinants of the CRS that were not controlled for such as flood insurance demand (Dixon et al., 2006; Zahran et al., 2009) and flood insurance claims (Kousky \& Michel-Kerjan, 2015). Future research should endeavor to build upon our study by including these and other omitted, but relevant control variables. Third, it is imperative to know whether the increased construction of new housing in the floodplain observed in this study is elevated in compliance with the NFIP requirements (Burby, 2001). The current study is not able to ascertain this. As such, future studies should extend our work by determining whether or not the new houses developed in floodplains are in compliance with NFIP regulations. Fourth, the study employed a time-invariant measure of flood risk. A time-varying measure of flood risk would allow for the effects of CRS on flood risk to be differentiated from its other effects. We therefore recommend future research to use a time-varying measure of flood risk. Similarly, more localized measures of flood damage would shed more light on recovery and resilience beyond what our limited measure can tell us. Finally, we recognize that the CRS might have 
some welfare effects. However, an investigation of this possibility is beyond the scope of this study. Therefore, we recommend that future studies examine the welfare effects of participating in the CRS program. Despite these limitations, we are confident that this national-level study will benefit both academics and practitioners by helping to illuminate the impacts of the CRS program on migration and development, and in doing so, increase our understanding of the effects of community-scale flood risk management on ecological and human systems.

\section{References}

Bagstad, K. J., Stapleton, K., \& D'Agostino, J. R. (2007). Taxes, subsidies, and insurance as drivers of United States coastal development. Ecological Economics, 63(2), 285-298.

Barnard, J. R. (1978). Externalities from urban growth: The case of increased storm runoff and flooding. Land Economics, 54(3), 298-315.

Beierle, C. T. (2004). The benefits and costs of disclosing information about risks: What do we know about right-to-know? Risk Analysis, 24(2), 335-346.

Bollens, S. A., Kaiser, E. J., \& Burby, R. J. (1989). Private profit and public safety as outcomes of local land-use regulation. Environment and Planning B: Planning and Design, 16(1), 7-22.

Botzen, W. J., Aerts, J. C., \& van den Bergh, J. C. (2009). Willingness of homeowners to mitigate climate risk through insurance. Ecological Economics, 68(8), 2265-2277.

Boustan, L. P., Kahn, M. E., \& Rhode, P. W. (2012). Moving to higher ground: Migration response to natural disasters in the early twentieth century. The American Economic Review, 102(3), 238-244.

Brody, S. D., Blessing, R., Sebastian, A. \& Bedient, P. (2012). Delineating the reality of flood risk and loss in Southeast Texas. Nat Hazards Review, 14(2), 89-97.

Brody, S. D., Zahran, S., Highfield, W. E., Bernhardt, S. P., \& Vedlitz, A. (2009). Policy learning for flood mitigation: A longitudinal assessment of the Community Rating System in Florida. Risk Analysis, 29(6), 912-929.

Brody, S. D., Zahran, S., Highfield, W. E., Grover, H., \& Vedlitz, A. (2008). Identifying the impact of the built environment on flood damage in Texas. Disasters, 32(1), 1-18.

Brody, S. D., Zahran, S., Maghelal, P., Grover, H., \& Highfield, W. E. (2007). The rising costs of floods: Examining the impact of planning and development decisions on property damage in Florida. Journal of the American Planning Association, 73(3), 330-345.

Browne, Mark J., Carolyn A. Dehring, David L. Eckles, and William D. Lastrapes. 2015. Does National Flood Insurance Program Participation Induce Housing Development? 28 August 2015. Working Paper. 
Burby, R. J. (2001). Flood insurance and floodplain management: The US experience. Environmental Hazards, 3(3-4), 111-122.

Burby, R. J. (2006). Hurricane Katrina and the paradoxes of government disaster policy: Bringing about wise governmental decisions for hazardous areas. The Annals of the American Academy of Political and Social Science, 604(1), 1-22.

Chakraborty, J., Collins, T. W., Montgomery, M. C., \& Grineski, S. E. (2014). Social and spatial inequities in exposure to flood risk in Miami, Florida. Natural Hazards Review, 15(3). doi:10.1061/(ASCE)NH.1527-6996.0000140

Cordes, J. J. \& Yezer, A. M. J. 1998. In Harm's Way: Does Federal Spending on Beach Enhancement and Protection Induce Excessive Development in Coastal Areas? Land Economics, 74(1):128-145.

Department of Homeland Security. (2013). Federal Emergency Management Agency National Flood Insurance Fund. Retrieved from https://www.fema.gov/pdf/about/budget/11h_fema_nfi_fund_dhs_fy13_cj.pdf

Dixon, L., Clancy, N., Seabury, S. A., \& Overton, A. (2006). The National Flood Insurance Program's market penetration rate, estimates and policy implications. Rand. Retrieved from http://www.rand.org/content/dam/rand/pubs/technical reports/2006/RAND TR300.pdf

Fessenden, F., Gebeloff, R., Walsh, M. W. \& Griggs, T. (2017). "Water damage from hurricane harvey extended far beyond flood zones." New York Times. Retrieved from https://www.nytimes.com/interactive/2017/09/01/us/houston-damaged-buildings-infema-flood-zones.html

Federal Emergency Management Agency. (2015). Special Flood Hazard Areas. Retrieved from http://www.fema.gov/special-flood-hazard-area.

Federal Emergency Management Agency. (2016). Community Rating System Fact Sheet. Retrieved from https://www.fema.gov/media-library/assets/documents/9998

Federal Emergency Management Agency. (2017). National Flood Insurance Program (NFIP) Community Rating System (CRS) Coordinator Manual. Retrieved from http://www.fema.gov/media-library/assets/documents/8768?id=2434

Filatova, T. (2014). Market-based instruments for flood risk management: a review of theory, practice and perspectives for climate adaptation policy. Environmental science \& policy, $37,227-242$.

Finger, S. R., \& Gamper-Rabindran, S. (2013). Mandatory disclosure of plant emissions into the environment and worker chemical exposure inside plants. Ecological Economics, 87, 124-136. 
Geaves, L. H., \& Penning-Rowsell, E. C. (2016). Flood risk management as a public or a private good, and the implications for stakeholder engagement. Environmental Science \& Policy, 55, 281-291.

Guha-Sapir, D., Hoyois, P., \& Below, R. (2013). Annual disaster statistical review 2012: The numbers and trends. Retrieved from http://reliefweb.int/sites/reliefweb.int/files/resources/ADSR_2012.pdf

Hornbeck, R., \& Naidu, S. (2014). When the levee breaks: black migration and economic development in the American South. The American Economic Review, 104(3), 963-990.

Husby, T. G., Groot, H. L., Hofkes, M. W., \& Dröes, M. I. (2014). Do floods have permanent effects? Evidence from the Netherlands. Journal of Regional Science, 54(3), 355-377.

Intergovernmental Panel on Climate Change (IPCC). (2013). Summary for Policymakers. In Stocker T. F., Qin, D., Plattner, G. K., Tignor, M., Allen, S. K, Boschung, J., Nauels, A., Xia, Y., Bex, V., \& Midgley, P. M. (Eds.), Climate Change 2013: The Physical Science Basis. Contribution of Working Group I to the Fifth Assessment Report of the Intergovernmental Panel on Climate Change (33-115). Cambridge, United Kingdom and New York, NY, USA: Cambridge University Press.

Jonkman, S. N. (2005). Global perspectives on loss of human life caused by floods. Natural Hazards, 34(2), 151-175.

Kahn, M. E. (2015). Climate Change Adaptation: Lessons from Urban Economics. Strategic Behavior and the Environment, 5(1), 1-30.

Kousky, C. (2010). Using natural capital to reduce disaster risk. Journal of Natural Resources Policy Research, 2(4), 343-356.

Kousky, C., \& Michel-Kerjan, E. (2015). Examining flood insurance claims in the United States: Six key findings. Journal of Risk and Insurance. DOI: 10.1111/jori.12106

Kousky, C., \& Zeckhauser, R. (2006). JARring actions that fuel the floods. In Ronald J. Daniels, Donald F. Kettl, and Howard Kunreuther (eds.), On risk and disaster: Lessons from Hurricane Katrina. Philadelphia: University of Pennsylvania Press, 59-73

Landry, C. E., \& Li, J. (2012). Participation in the Community Rating System of NFIP: Empirical analysis of North Carolina counties. Natural Hazards Review, 13(3), 205-220.

Li, J., \& Landry, C. E. (2014). Flood risk, local hazard mitigation, and the community rating system of NFIP. Social Science Research Network. Retrieved from http://papers.ssrn.com/sol3/papers.cfm?abstract id=2516525

Noonan, D., Richardson, L., \& Sadiq, A. A. (2018). Policy diffusion in community-scale flood risk management. WIT Transactions 
Noonan, D., \& Sadiq, A. A. (2018). Flood Risk Management: Exploring the Impacts of the Community Ratings System Program on Poverty and Income Inequality. Risk Analysis. 38(3), 489-503.

Olson, K. R., \& Morton, L. W. (2013). Impacts of 2011 Len Small levee breach on private and public Illinois lands. Journal of Soil and Water Conservation, 68(4), 89A-95A.

Petrolia, D. R., Landry, C. E., \& Coble, K. H. (2013). Risk preferences, risk perceptions, and flood insurance. Land Economics, 89(2), 227-245.

Portnykh, M. (2014). Essays on adaptation to climate change (Doctoral Dissertation). Clemson University.

Posey, J. (2009). The determinants of vulnerability and adaptive capacity at the municipal level: Evidence from floodplain management programs in the United States. Global Environmental Change, 19(4), 482-493.

Pramova, E., Locatelli, B., Djoudi, H., \& Somorin, O. A. (2012). Forests and trees for social adaptation to climate variability and change. Wiley Interdisciplinary Reviews: Climate Change, 3(6), 581-596.

Reddy, S. D. (2000). Examining hazard mitigation within the context of public goods. Environmental management, 25(2), 129-141.

Richert, C., Erdlenbruch, K., \& Figuières, C. (2017). The determinants of households' flood mitigation decisions in France-on the possibility of feedback effects from past investments. Ecological Economics, 131, 342-352.

Roth Sr, R. J., \& Kunreuther, H. (Eds.). (1998). Paying the Price: The Status and Role of Insurance against Natural Disasters in the United States. Washington, DC: Joseph Henry Press.

Rupasingha, A., \& Goetz, S. J. (2007). Social and political forces as determinants of poverty: A spatial analysis. The Journal of Socio-Economics, 36, 650-671.

Sadiq, A. A., \& Noonan, D. S. (2015a). Flood disaster management policy: An analysis of the United States Community Ratings System. Journal of Natural Resources Policy Research, 7(1), 5-22.

Sadiq, A. A., \& Noonan, D. S. (2015b). Local capacity and resilience to flooding: Community responsiveness to the Community Ratings System Program incentives. Natural Hazards, 78(2), 1-16.

Sant'Anna, A. A. (2018). Not So Natural: Unequal Effects of Public Policies on the Occurrence of Disasters. Ecological Economics, 152, 273-281. 
Thomas, A., \& Leichenko, R. (2011). Adaptation through insurance: lessons from the NFIP. International Journal of Climate Change Strategies and Management, 3(3), 250-263.

United States Department of Transportation. (1996). Natural disaster study: National pipeline risk index technical report (Task 2). U.S. Department of Transportation, Research and Special Programs Administration, Office of Pipeline Safety.

Wu, X., \& Cutter, B. (2011). Who votes for public environmental goods in California? Evidence from a spatial analysis of voting for environmental ballot measures. Ecological Economics, 70(3), 554-563.

Zahran, S., Brody, S. D., Highfield, W. E., \& Vedlitz, A. (2010). Non-linear incentives, plan design, and flood mitigation: The case of the Federal Emergency Management Agency's Community Rating System. Journal of Environmental Planning and Management, 53(2), 219-239.

Zahran, S., Weiler, S., Brody, S. D., Lindell, M. K., \& Highfield, W. E. (2009). Modeling National Flood Insurance Policy holding at the county scale in Florida, 1999-2005. Ecological Economics, 68(10), 2627-2636. 